\title{
CHANGES IN CONCENTRATIONS AND LOADS OF TOTAL PHOSPHORUS IN DOMESTIC AND TREATED WASTEWATER OVER A 15-YEAR OBSERVATION PERIOD IN TERMS OF LIMITING NEGATIVE ANTHROPOPRESSURE ON THE QUALITY OF SURFACE WATER - CASE STUDY
}

\author{
Grzegorz Bogusław Kaczor ${ }^{\bowtie}$ \\ Department of Sanitary Engineering and Water Management, Faculty of Environmental Engineering and Land Surveying, \\ University of Agriculture in Krakow, al. Mickiewicza 24/28, 30-059 Krakow
}

\begin{abstract}
Aim of the study

The main aim of the research was to verify the thesis that formal and legal restrictions on the use of phosphorus compounds, particularly polyphosphates, in detergents extensively introduced in recent years reduced the concentration and load of this nutrient in raw sewage inflowing to the selected treatment plant. Additionally, it was tested whether the phosphorus decreasing in raw sewage reduced the concentrations and loads of total phosphorus in treated sewage, and thus reduced negative sewage anthropopressure of the water body.
\end{abstract}

\begin{abstract}
Material and methods
This paper presents observations accumulated during the 15-years study (2003-2015), the concentrations and loads of total phosphorus in domestic sewage flowing into the selected treatment plant, as well as in treated sewage discharged into the receiving water body. A total of 148 samples of raw sewage and 114 samples of treated sewage were collected over the research period. The concentration of the total phosphorus in wastewater was determined by spectrometry with ammonium molybdate. The research results were analysed with the aid of advanced statistical analysis using, among others Mann-Kendall test, Kolmogorov Smirnov test, elements of descriptive statistics, as well as regression analysis with selected significance tests.
\end{abstract}

\section{Results and conclusions}

Based on the research, it was stated that multidirectional activities implemented both in Poland and Europe with the view to phosphates limitation in detergents have significantly reduced the concentration and load of this nutrient in domestic sewage inflowing to the treatment plant. Over the past 15 years, the total phosphorus concentration in household wastewater has decreased from 14.4 to $5.7 \mathrm{mg} \cdot \mathrm{dm}^{-3}$, i.e. by $60.4 \%$. The observed tendency corresponds to the decrease in the unit load value per 1 inhabitant. This parameter decreased by $68 \%$ from $2.25 \mathrm{mg} \cdot$ person $^{-1} \cdot \mathrm{d}^{-1}$ in 2003 to $0.72 \mathrm{mg} \cdot$ person $^{-1} \cdot \mathrm{d}^{-1}$ in 2017 . The total phosphorus concentration in treated sewage discharged from the tested sewage treatment plant decreased from 5.1 to $2.0 \mathrm{mg} \cdot \mathrm{dm}^{-3}$, i.e. by $60.8 \%$, in the years $2003-2017$. The observed regression of phosphorus content in the wastewater discharged into the sewage system translates into lowered risk of anthropopressure for flowing waters and the Baltic Sea, mainly in the aspect of initiating the eutrophication process. Based on the research, it was found 
that only for one analysed sewage treatment plant, the annual phosphorus content in the wastewater would reduce the trophic mass growth by nearly 33 tons, in comparison to the period when no restrictions were applied to the content of polyphosphate in detergents.

Keywords: wastewater, sewage, Total phosphorus, treatment plant, negative anthropopressure

\section{INTRODUCTION}

The trend of increasing atmospheric air temperature that has been sustained for a long time exerts a continuous and clear impact on global, but also local, climate changes (Szpakowski and Szydłowski 2018, Anderson et al., 2016). An increase in temperature promotes the formation of areas covered by drought or desertification (Travis et al., 2018). In Poland, the ensuing climate changes gradually reduce the thickness of snow cover in the winter, which so reduces river flows, but at the same time, in the summer, they generate intensive rainfall, thus causing destructive flood conditions (Ziernicka-Wojtaszek and Krużel, 2016; Wałęga et al., 2016; Wałega and Michalec, 2014). In recent years, a steady decline in the groundwater levels and reduction in the capacity of underground water reservoirs has been observed. All of these results in a reduction of water resources available to Polish residents (Dąbrowska et al., 2017). In the years 1980-2020, the unit volume of water per capita is gradually decreasing. In 1980, this value was $2,500 \mathrm{~m}^{3}$, and in recent years it varied between 1,000 and 1,600 $\mathrm{m}^{3}$ per person. For comparison, in Europe, it is on average about $4,900 \mathrm{~m}^{3}$ per capita per year (Majewski, 2015). With regard to these unfavorable changes, Poland's priority task at the moment is a multi directional protection of surface and underground waters, and their management in the most sustainable way.

One of the greatest threats to surface water is the anthropopressure related to the discharge of various pollutants (Cupak et al., 2019; Sojka et al., 2016; Policht-Latawiec et al., 2014). Among those especially harmful to flowing waters, mainly water basins, are all the phosphorus compounds (Moges et al., 2017; Ciml et al., 2015; Górecki, 2007). They contribute to trophy, i.e. an increase in the aquatic ecosystem fertility, which results in the eutrophication process (Wasag, 2008). In water reservoirs and watercourses, the decomposition of excessive growth of the biomass generated by wa- ter microorganisms can lead to oxygen deficiency. In the waters of the Baltic Sea, phosphorus compounds contribute to the excessive growth of phytoplankton organisms, and above all, the blooms of cyanobacteria, which are toxic to humans.

Phosphorus from domestic sewage collected in sewage networks is removed in sewage treatment plants, in either biological or chemical processes. Biological phosphorus disposal requires a proper type of multi-chamber activated sludge reactors, and the dephosphating process itself is quite difficult to run and to monitor (Chmielowski et al., 2019; Wałęga et al., 2019; Wałęga et al., 2010). Effective removal of nutrients is possible mainly in large collective wastewater treatment plants, enabling the technical and technological capacity for increased removal of nutrients. For small facilities with less than 2,000 PE (Population Equivalent), biological phosphorus removal is generally negligible (Marzec 2018, 2017). In addition, it is sanctioned by applicable legislation (Rozporządzenie..., 2019). However, taking into account the number of this type of treatment plants in Poland, it becomes clear what significant threat to small watercourses is posed by the loads of the aforementioned nutrients discharged together with insufficiently treated sewage.

Another important source of phosphorus in domestic sewage is, among others, the washing powder used for washing machines, dishwashers and to keep rooms in residential or public buildings clean (Giagnorio et al., 2017). For many years, intensive and multi directional activities have been carried out to reduce the polyphosphate content in washing powder. In Europe and the USA, the first restrictions on phosphorus in laundry washing powder were introduced as early as 1965 (Kogawa et al., 2017). In Poland, the first formal actions of this type was undertaken during the country's accession to the European Union, as reflected in the content of the Regulation of the Minister of Economy, Labour and Social Policy of June 
26, 2003 on detailed requirements for some products due to their negative impact on the environment (Rozporządzenie... 2003). This document establishes a minimum of $80 \%$ as the degree of partial biodegradation of anionic and non-ionic surfactants contained in washing and cleaning products. An acceptable phosphate content of up to $6 \%$ was also determined for washing and cleaning products. After Poland's accession to the European Union (1 May 2004), the Regulation of the Minister of Economy and Labour of July 23, 2004 on detailed requirements for some products due to their negative impact on the environment was introduced. In the European Union legislation, the content of phosphates in washing powder is regulated by Regulation (EU) No 259/2012 of the European Parliament and of the Council of March 14, 2012 on the consumer use of phosphates and other phosphorus compounds in laundry washing powder and automatic dishwashers. According to this document (Annex VIa), from 30 June 2013, no laundry washing powder for consumer use may be placed on the market with the total phosphorus content equal to or exceeding $0.5 \mathrm{~g}$ during the main wash cycle. From January 1, 2017, the marketing of consumer washing powder for automatic dishwashers is restricted if the total phosphorus content is equal to or greater than $0.3 \mathrm{~g}$ per standard dosage.

Therefore, as follows from the above, multi directional actions have been taken to reduce the phosphorus compound loads in domestic sewage discharged into the sanitary sewage system in Poland since 2003, i.e. for the last 17 years. Nevertheless, no results of long-term studies are available in open-access literature that would document a measurable effect of the discussed activities or their contribution to the concentration and load of total phosphorus reduction in sewage discharged from households to the sewage system. To obtain such data, this study observes changes in the concentration and load of total phosphorus in domestic sewage flowing into the selected sewage treatment plant, as well as in the treated sewage discharged from this facility to the receiving water body, over a 15 -year study period.

The main purpose of the research is to verify the assumption that formal and legal restrictions on the use of phosphorus compounds, and polyphosphates in particular, introduced in recent years, led to the reduc- tion of the concentration and load of phosphorus in raw and treated sewage discharged into the receiving water body.

The results of such studies intend to prove the dynamics of the process of decreasing negative anthropopressure on surface water quality in Poland.

\section{MATERIALS AND METHODS}

Analysis of the variability of concentrations and loads of total phosphorus in domestic sewage was carried out in the inlet channel to the mechanical and biological sewage treatment plant, and in the channel discharging treated sewage to the receiving water body.

The research facility is located in the Małopolska Region, on the outskirts of the Krakow agglomeration, $12 \mathrm{~km}$ from the centre of Krakow. The sewage treatment plant, to which domestic sewage is flowing, has a hydraulic capacity of $650 \mathrm{~m}^{3} \cdot \mathrm{d}^{-1}$. The technological system of the facility includes Huber sieve, Imhoff settler, biological reactor of activated sludge (with separated anaerobic, anoxic and aerobic zones), and vertical secondary settler. The facility has been in operation since 1999. Although a three-phase reactor is used in the sewage treatment plant, the permissible concentration of biogenic compounds discharged to the receiver was not included in the applicable water-legal permit. The receiving body for the treated sewage is a nameless stream, which is a right-bank tributary of the Vistula river.

Household sewage flows into the sewage treatment plant by a gravitational distribution sewer network, with a total length of $22 \mathrm{~km}$, made of vitrified clay pipes with diameters from 200 to $400 \mathrm{~mm}$. In the analysed sewage basin, apart from single-family residential buildings, there are rarely any arable or green areas. Most of the residents of the estate work in Krakow city or run small service establishments within their properties (shops, workshops, florists, etc.).

There are no large industrial facilities within the drainage basin area. A typical household, from which sewage discharges, typically consists of 4 to 6 people. On average, sewage from a residential household is produced in 2 bathrooms and in 1 kitchen. Hot water is heated locally in the building by means of a gas combi boiler or a volumetric electric heater. It is standard for the kitchens to use sinks and dishwashers. In 
both bathrooms, there are usually 2 water flush toilets bowls, bathtubs, showers, and washstands. The estate is supplied with water from the collective water supply system of the Krakow city.

Analyses of the wastewater quality outflowing from the analysed housing estate continued for 15 years (from 1 January 2003 to 31 December 2017). As part of the specific research, the following pollution indicators were analysed: $\mathrm{BOD}_{5}, \mathrm{COD}$, total suspension, all forms of nitrogen, total phosphorus, chlorides, and sulfates. In this work, only the data on the total phosphorus concentration in the wastewater was used. $\mathrm{BOD}_{5}$, COD and total nitrogen values were used as data supporting the interpretation of the results. Throughout the study period, 148 raw sewage samples and 114 treated sewage samples were collected. Total phosphorus concentration in the wastewater was determined by spectrometer with ammonium molybdate, by PN-EN 6878: 2006. Analysis of sewage composition was carried out in an accredited laboratory in Krakow.

The obtained series of measurement data was verified in terms of incorrectly recorded values and outliers. For Grubbs test to be applied in order to find outliers, statistical normality of data distribution had been tested using the Kolmogorov Smirnov test with Lillefors correction. By means of the Statistica program, it was determined that there is no reason to reject the $\mathrm{H} 0$ hypothesis assuming that the analysed data have a normal distribution. The null hypothesis was adopted, at the assumed significance level of $\alpha=0.05$, because this value is less than the p-value probability test of 0.235 . Grubbs test showed 3 outliers. However, these data were not discarded, because they were the directing point regression line. In later stages of the study, the Mann-Kendall test, regression analysis, and Student's $t$ test were used. Most analyses were performed in Statistica or Excel programs.

\section{RESULTS AND DISCUSSION}

In the first stage of the analysis, a plot of total phosphorus concentration in raw wastewater versus time axis was made. The Mann-Kendall test was used to confirm whether the concentration of tested nitrogen is also following a trend. The calculations of the test were made in an Excel spreadsheet developed by the author. The H0 hypothesis assumes that the data are not subject to any trend, i.e. the concentration of total phosphorus does not decrease over the multi annual period 2003-17, while the alternative H1 hypothesis assumes that such a trend does occur. On the adopted level of significance $\alpha=0.05$, the H0 hypothesis was rejected (p-value $<0.0001$ ). The confirmation of the downward trend is the value of the statistics $Z=-8.14$, with $S=-4900$ and Kendall's value Tau $=-0.450$. The test result indicates that as time progresses, in the years 2003-2017, the concentration of total phosphorus decreases monotonically.

Following the trend, a regression line was developed in the spreadsheet, illustrating the correlation between total phosphorus concentration and time (see: Fig. 1).

The highest conformity adjustment $\left(R^{2}=0.42\right)$ was obtained for the power function of the form $y=a \cdot x^{b}$. The estimation of non-linear function parameters requires its transformation, which affects the uncertainty of the results. Finally, the concentration of total phosphorus in raw sewage describes the linear function in the form of $y=-0,0017 \cdot x+14.42$. The " $y$ " characteristic means the phosphorus concentration in the wastewater, and " $x$ " denotes time counted from 01.01.2003. The value of the determination coefficient $\mathrm{R}^{2}$ for the linear function was 0.40 . That is, the regression line fit to empirical data only deteriorated by $2 \%$. The equation parameters estimation made in the Statistica program showed that they are statistically significant (beta $=-0.64)$. The Student's t-test showed that at the assumed significance level $\alpha=0.05$, the $p$-value is less than 0.0001 for the gradient $t=-9.38$, while for the $y$-intercept $t=27.83$. The error of gradient estimation is 0.0002 , while the error of y-intercept estimation is 0.52 . The linear model significance was tested using the $\mathrm{F}$ (Fisher-Snedecor) test. The statistics results were $F=87.94$ with degrees of freedom $d f=1.130$. On the assumed level of significance $\alpha=0.05$, the null hypothesis with linear insignificance between the analysed variables was rejected ( $p$-value $<0.0001$ ).

The equation parameters fit was considered to be correct. Then, the average value of total phosphorus concentration in the raw wastewater in analysed years was calculated. While the equation parameters fit was considered to be correct, the calculation of the average value of the total phosphorus concentration in the wastewater flowing into the tested sewage treatment 


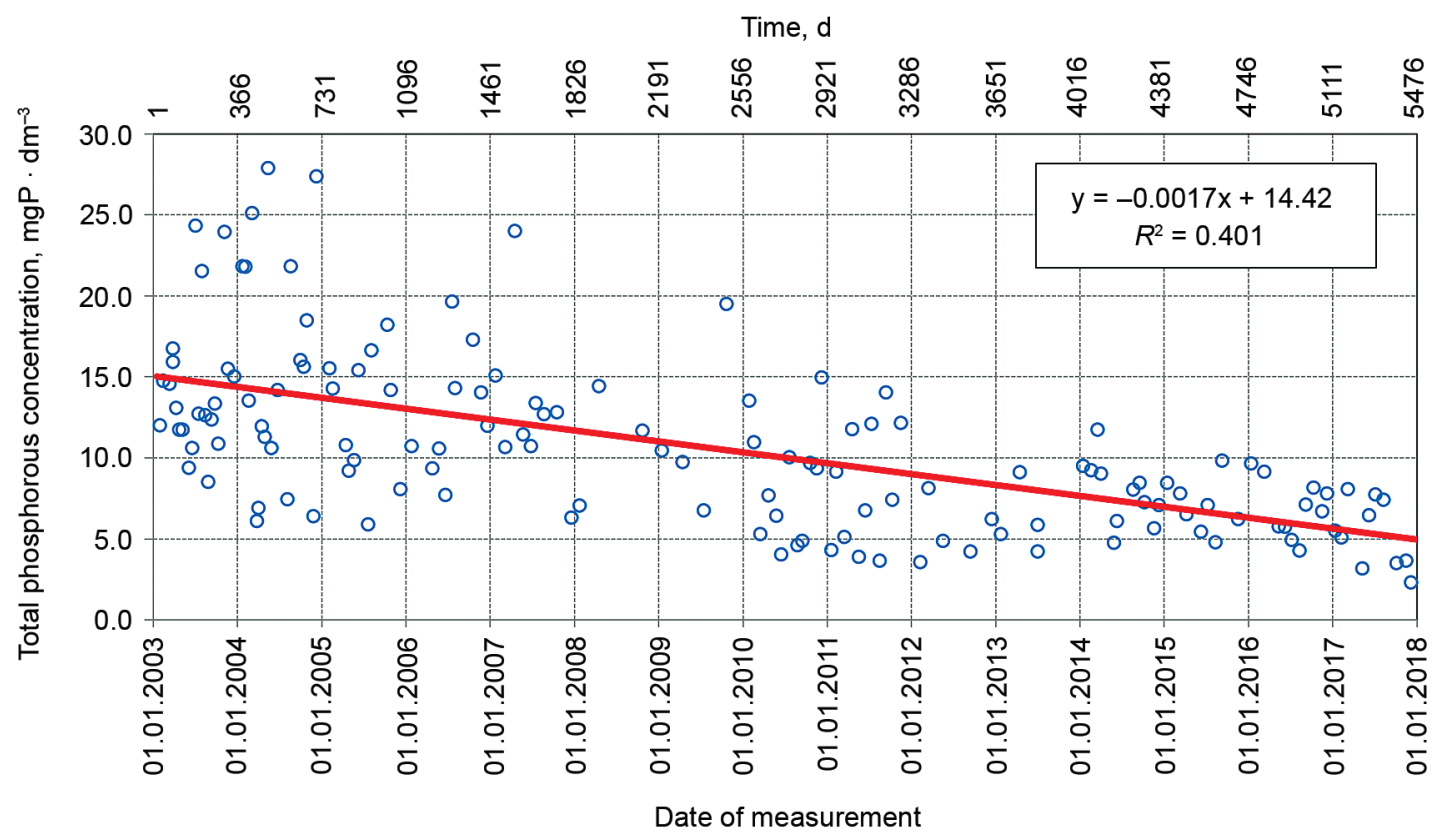

Fig. 1. Scatter plot and regression line describing decreasing trend of total phosphorus concentration in raw sewage in the analysed years 2003-2017

plant in individual years was made. The calculation results are presented in Table 1.

At the beginning of the study period, in 2003 , the total phosphorus concentration in the raw sewage was $15.0 \mathrm{mg} \cdot \mathrm{dm}^{-3}$. At the end of the research period, i.e. in 2017 , the analysed nutrient concentration decreased by $60.1 \%$ to $5.9 \mathrm{mg} \cdot \mathrm{dm}^{-3}$. Every year, the phosphorus concentration was reduced - on average, by $6.5 \%$. It was also observed that the total phosphorus concentration variability in wastewater decreases annually. This confirms the value of the standard deviation, which in 2003 was $4.3 \mathrm{mg} \cdot \mathrm{dm}^{-3}$, and in 2017 only $0.7 \mathrm{mg} \cdot \mathrm{dm}^{-3}$.

The values of total phosphorus load in raw sewage were then analysed. With the average daily flow of sewage inflow in $\mathrm{m}^{3} \cdot \mathrm{d}^{-1}$, the average daily load of total phosphorus in the sewage flowing into the treatment plant is calculated (see: Table 1). Analysing the obtained data, it is seen that despite the increasing number of sewerage users and growing intensity of sewage inflow every year, the load of the studied nutrient gradually decreased from $6.37 \mathrm{~kg} \cdot \mathrm{d}^{-1}$ in 2003 to $3.75 \mathrm{~kg} \cdot \mathrm{d}^{-1}$ in 2017 . Thus, the total phosphorus load in raw sewage decreased by $41.1 \%$.
In this type of research, it is important to find whether the decrease in phosphorus concentration is associated with dilution of wastewater by infiltration or / and accidental waters. In this case, the values of other contamination indicators, such as $\mathrm{BOD}_{5}, \mathrm{COD}$ or total suspension should be supported. Research conducted by Kaczor (2012) and Kaczor et al. (2015, 2017) indicates that with the extraneous waters' contribution in the wastewater, the values of most pollution indicators decreased. Zawilski and Brzezińska (2003) also point out the diluting phosphorus possibility during wet weather. Figure 2 shows the changes in $\mathrm{BOD}_{5}$ values in raw domestic sewage in the analysed period of 2003-2018. No trend is observed here. The presented chart shows that even since $2015, \mathrm{BOD}_{5}$ values have increased periodically, perhaps due to the inflow of concentrated sewage. No such phenomenon is observed in Figure 1. Similarly, significant dilution of the contamination is observed for COD and total suspension. Only in the case of total nitrogen, a statistically insignificant decreasing trend is also visible.

The global value of phosphorus load in raw sewage is poorly comparable. In terms of treatment plants design and the conducting of technological process- 
Kaczor, G. B. (2020). Changes in concentrations and loads of total phosphorus in domestic and treated wastewater over a 15 -year observation period in terms of limiting...Acta Sci. Pol., Formatio Circumiectus, 19 (2), 3-14. DOI: http://dx.doi.org/10.15576/ASP.FC/2020.19.2.3

Table 1. Summary of the selected parameters of wastewater treatment plant operating and total phosphorus concentrations and loads in a raw and treated wastewater

\begin{tabular}{|c|c|c|c|c|c|c|c|c|c|c|c|c|c|c|c|c|}
\hline \multirow{2}{*}{$\frac{\text { Parameter }}{\text { Year }}$} & \multirow{2}{*}{ Unit } & \multicolumn{15}{|c|}{ Value of the parameter in a given year } \\
\hline & & 2003 & 2004 & 2005 & 2006 & 2007 & 2008 & 2009 & 2010 & 2011 & 2012 & 2013 & 2014 & 2015 & 2016 & 2017 \\
\hline \multicolumn{17}{|c|}{ Wastewater treatment plant } \\
\hline $\begin{array}{c}\text { Average } \\
\text { daily } \\
\text { wastewater } \\
\text { flow }\end{array}$ & {$\left[\mathrm{m}^{3} \cdot \mathrm{d}^{-1}\right]$} & 424.5 & 439.5 & 454.6 & 469.6 & 484.6 & 499.7 & 514.7 & 529.7 & 544.8 & 559.8 & 574.8 & 589.9 & 604.9 & 619.9 & 635.0 \\
\hline $\begin{array}{l}\text { Population } \\
\text { equivalent } \\
\text { (PE) }\end{array}$ & {$[-]$} & 2830 & 2970 & 3113 & 3261 & 3413 & 3569 & 3730 & 3895 & 4065 & 4241 & 4422 & 4608 & 4801 & 4999 & 5205 \\
\hline \multicolumn{17}{|c|}{ Raw wastewater } \\
\hline $\begin{array}{c}\text { Total } \\
\text { phosphorus } \\
\text { concentra- } \\
\text { tion with } \\
\text { standard } \\
\text { deviation }\end{array}$ & {$\left[\mathrm{mg} \cdot \mathrm{dm}^{-3}\right]$} & $\begin{array}{r}14.4 \\
\pm 4.3\end{array}$ & $\begin{array}{r}13.8 \\
\pm 7.2\end{array}$ & $\begin{array}{r}13.2 \\
\pm 4.0\end{array}$ & $\begin{array}{r}12.6 \\
\pm 3.9\end{array}$ & $\begin{array}{r}11.9 \\
\pm 4.8\end{array}$ & $\begin{array}{r}11.3 \\
\pm 3.7\end{array}$ & $\begin{array}{l}10.7 \\
\pm 5.5\end{array}$ & $\begin{array}{r}10.1 \\
\pm 3.6\end{array}$ & $\begin{array}{r}9.5 \\
\pm 3.8\end{array}$ & $\begin{array}{r}8.8 \\
\pm 1.8\end{array}$ & $\begin{aligned} & 8.2 \\
\pm & 2.1\end{aligned}$ & $\begin{array}{r}7.6 \\
\pm 2.0\end{array}$ & $\begin{array}{r}7.0 \\
\pm 1.6\end{array}$ & $\begin{array}{r}6.3 \\
\pm 1.8\end{array}$ & $\begin{array}{r}5.7 \\
\pm 0.7\end{array}$ \\
\hline $\begin{array}{c}\text { Total } \\
\text { phosphorus } \\
\text { load }\end{array}$ & {$\left[\mathrm{kg} \cdot \mathrm{d}^{-1}\right]$} & 6.12 & 6.07 & 5.99 & 5.90 & 5.78 & 5.65 & 5.50 & 5.34 & 5.15 & 4.94 & 4.72 & 4.48 & 4.22 & 3.94 & 3.64 \\
\hline $\begin{array}{c}\text { Unit load } \\
\text { of total } \\
\text { phosphorus }\end{array}$ & $\begin{array}{l}{\left[\mathrm{mg} \cdot \mathrm{d}^{-1} \cdot\right.} \\
\left.\cdot \text { person }^{-1}\right]\end{array}$ & 2.16 & 2.04 & 1.92 & 1.81 & 1.69 & 1.58 & 1.48 & 1.37 & 1.27 & 1.17 & 1.07 & 0.97 & 0.88 & 0.79 & 0.70 \\
\hline \multicolumn{17}{|c|}{ Treated wastewater } \\
\hline $\begin{array}{c}\text { Total } \\
\text { phosphorus } \\
\text { concentra- } \\
\text { tion }\end{array}$ & {$\left[\mathrm{mg} \cdot \mathrm{dm}^{-3}\right]$} & 5.1 & 4.4 & 3.7 & 3.4 & 3.1 & 2.9 & 2.7 & 2.6 & 2.5 & 2.4 & 2.3 & 2.2 & 2.1 & 2.0 & 2.0 \\
\hline $\begin{array}{c}\text { Total } \\
\text { phosphorus } \\
\text { load }\end{array}$ & {$\left[\mathrm{kg} \cdot \mathrm{d}^{-1}\right]$} & 2.16 & 1.92 & 1.70 & 1.58 & 1.51 & 1.45 & 1.41 & 1.38 & 1.35 & 1.33 & 1.31 & 1.30 & 1.28 & 1.27 & 1.26 \\
\hline $\begin{array}{l}\text { Efficiency } \\
\text { of total } \\
\text { phosphorus } \\
\text { removal }\end{array}$ & {$[\%]$} & 64.6 & 68.4 & 71.7 & 73.2 & 74.0 & 74.3 & 74.4 & 74.2 & 73.7 & 73.1 & 72.2 & 71.1 & 69.6 & 67.8 & 65.5 \\
\hline
\end{tabular}

es, the unit value of the phosphorus load is more important. This value mainly depends on the number of inhabitants. The latter number, as the key one in the calculations, was verified in many stages. The actual number of inhabitants registered in the housing estate was compared with the number of inhabitants calculated on the basis of the unit volume of sewage. In ad- dition, the actual number of residents registered in the housing estate was compared with the BOD unit load.

This number is verified as a key factor in the calculations. The actual number of inhabitants registered in the housing estate was compared to the conversion rate resulting from the unit volume of sewage and additionally with the conversion rate of p. e. calculated 


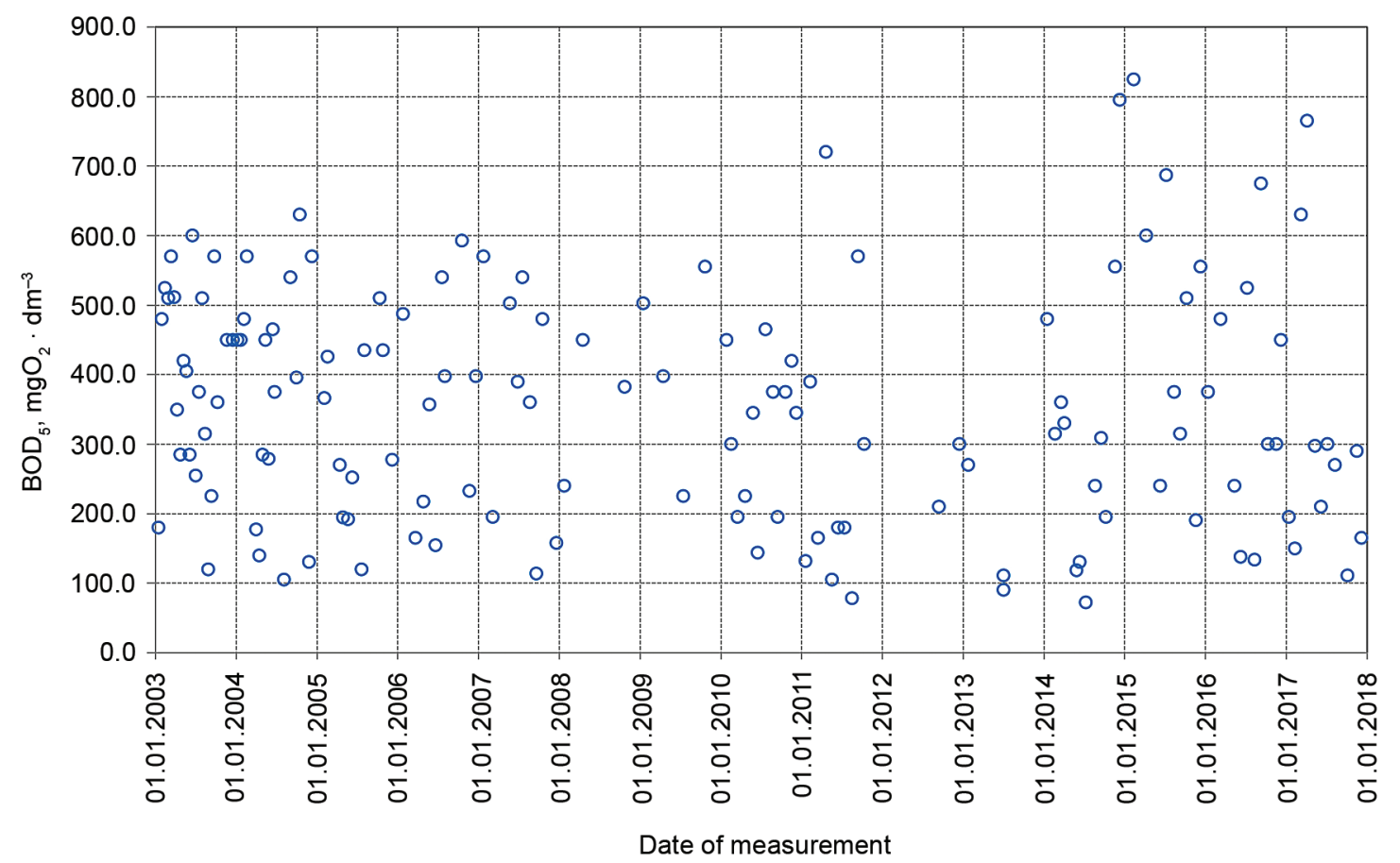

Fig. 2. Changes in the values of BOD5 in raw sewage in the years 2003-2017

on the basis of the $\mathrm{BOD}_{5}$ unit load in sewage. Data consistency was obtained for a unit volume of wastewater decreasing from $150 \mathrm{dm}^{3} \cdot$ person $^{-1} \cdot \mathrm{d}^{-1}$ in 2003 to $120 \mathrm{dm}^{3} \cdot$ person $^{-1} \cdot \mathrm{d}^{-1}$ in 2017 . The number of inhabitants thus determined and verified list Table 1, as PE. With the number of inhabitants and concentration value, the unit load of total phosphorus was calculated (see: Table 1). The results obtained are extremely important in the aspect of designing new sewage treatment plants. The studies have shown that the unit load of total phosphorus decreased by $68 \%$ from $2.25 \mathrm{mg} \cdot$ person $^{-1} \cdot \mathrm{d}^{-1}$ in 2003 to $0.72 \mathrm{mg} \cdot$ person $^{-1} \cdot \mathrm{d}^{-1}$ in 2017 , i.e. it decreased by $1.53 \mathrm{mg} \cdot$ person $^{-1} \cdot \mathrm{d}^{-1}$.

The last stage of the study was to analyse how the reduction of concentration (see: Fig. 3) and load of total phosphorus in raw sewage affected their treatment process and the concentration and load of this nutrient in treated sewage. The results of this analysis are listed in Table 1, in the part about the treated wastewater. We should note at this point that the sewage treatment plant enables biological dephosphatation of total phosphorus, through the anaerobic chamber with a capacity of $35 \mathrm{~m}^{3}$ separated in the reactor and the sewage retention time of 2.6 hours. It should be mentioned that, in accordance with the conditions of the water permit, in the analysed sewage treatment plant there is no requirement to reduce total phosphorus to the indicated value.

At the same time, under the water permit, a specific reduction of phosphorus is not required. The efficiency of phosphorus removal in the analysed object at the beginning of the study was $64.6 \%$. In later years, periodic variation was observed, gradually increasing to the value of $74.4 \%$ in 2009 , and then again decreasing to $65.5 \%$ in 2017 . This relationship shows that the trend of decreasing phosphorus concentration and load in raw sewage did not affect the monotonous increase in efficiency of the dephosphatation process. Deterioration of the sewage treatment plant operation efficiency may be related to its functioning under permanent hydraulic overload conditions at the end of the research period. Inflow of the raw sewage began to periodically exceed the design capacity of the analysed facility. 


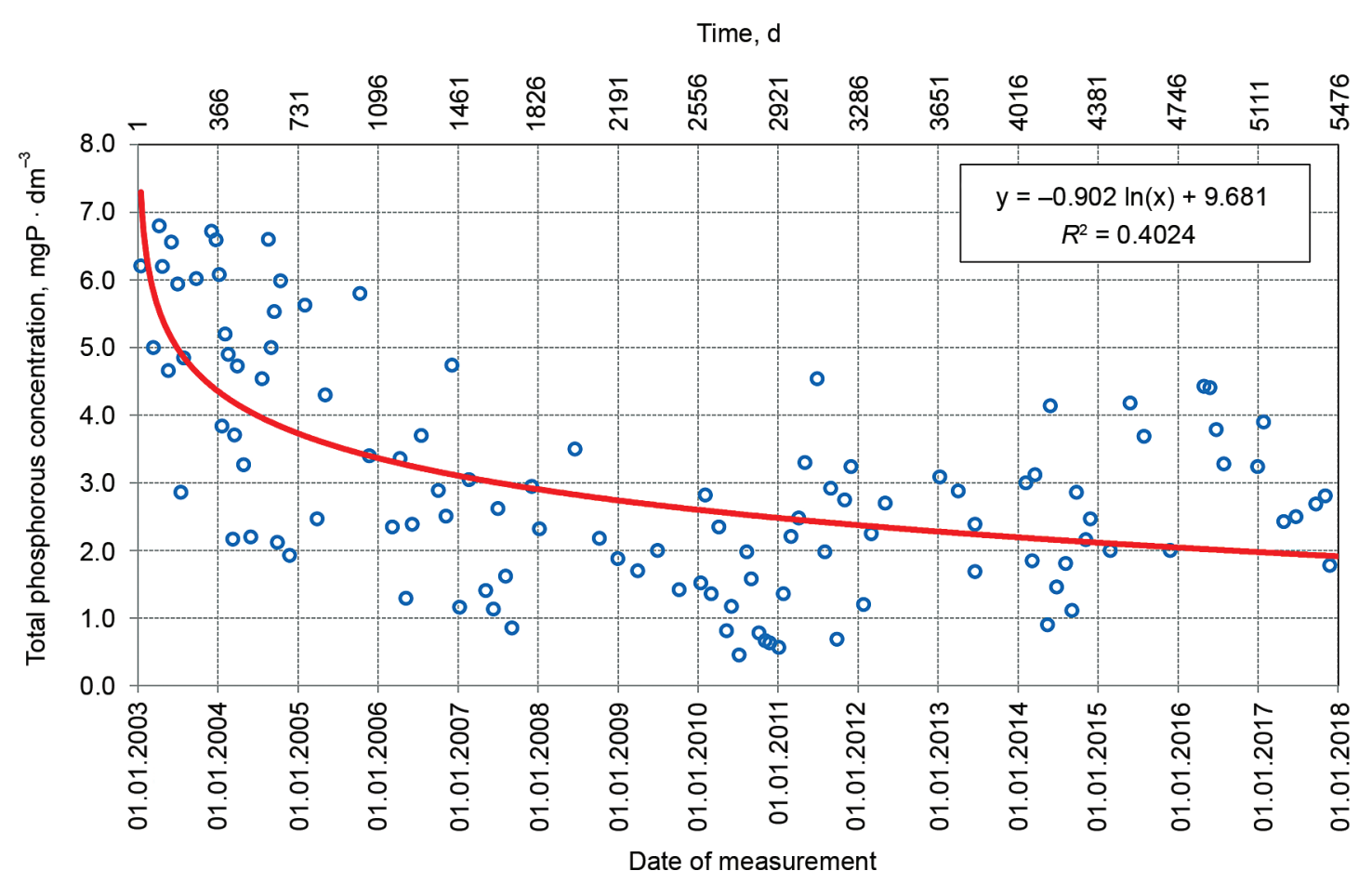

Fig. 3. Scatter plot and regression line describing decreasing trend of total phosphorus concentration in treated sewage in the analysed years 2003-2017

However, despite the average operational efficiency, probably due to the decreasing amount of phosphorus in the inflowing sewage, a constant trend of decreasing the concentration and load of this nutrient in the treated sewage is noticeable. The total phosphorus concentration in the treated sewage in the years 2003-2017 decreased from 5.1 to $2.0 \mathrm{mg} \cdot \mathrm{dm}^{-3}$, i.e. by $60.8 \%$. The change in phosphorus concentration in the treated wastewater, as much as $3.12 \mathrm{mg} \cdot \mathrm{dm}^{-3}$, is extremely important in terms of protecting the quality of the receiving water body. A similar correlation was found for the average daily load of total phosphorus in the treated sewage. In $2003,2.16 \mathrm{~kg} \cdot \mathrm{d}^{-1}$ of total phosphorus was discharged into the stream, which is a right-bank tributary of the Vistula river, while in 2017, the corresponding figure was only $1.26 \mathrm{~kg} \cdot \mathrm{d}^{-1}$. Therefore, the daily load of the nutrient, which is a trophic threat to the water, decreased by $0.90 \mathrm{~kg} \cdot \mathrm{d}^{-1}$, i.e. by $41.7 \%$. The obtained results are highly valuable in the context of efforts related to protecting the receiving water body against anthropopressure, due to the discharge of the treated sewage to the Vistula river and the Baltic Sea. In one year, 2003, $788 \mathrm{~kg}$ of total phosphorus was discharged into surface water within the treated wastewater from the analysed treatment plant. It is assumed that $1 \mathrm{~kg}$ of phosphorus can cause the growth of $100 \mathrm{~kg}$ trophic biomass (Dymaczewski, 2011), so theoretically $78,840 \mathrm{~kg}$ of algae may have grown from the discharged phosphorus. $11,826,000 \mathrm{~kg}$ of oxygen is needed to decompose such biomass (Dymaczewski, 2011). Multidirectional efforts related to the phosphorus reduction in wastewater have contributed to its reduction in washing agents. As a result of these efforts, in 2017, only $460 \mathrm{~kg}$ of total phosphorus was discharged from this treatment plant into the water body, and that could have been the cause of $46,000 \mathrm{~kg}$ of algal growth. To decompose this biomass, only $6,900,000 \mathrm{~kg}$ of oxygen will be needed, which is $4,926,000 \mathrm{~kg}$ less than in 2003.

Referring the obtained results to the results of studies by other authors, it should be stated that in selected studies one can also notice increased phosphorus concentrations and loads at the beginning of the multi annual period 2003-17 (Kaczor and Szewczyk, 
2011; Bugajski and Kaczor, 2004; Błażejewski, 2003; Henze et al., 2000). A publication by Maciołek et al. (2016) reports that the phosphorus concentration in a wastewater in 2005 is even higher than in this study, namely that it is $20 \mathrm{mg} \cdot \mathrm{dm}^{-3}$. The trend of decreasing total phosphorus concentration in wastewater in 2008-2011 has been observed in the aforementioned study by Maciołek et al. (2016). Interesting results of the total phosphorus content in wastewater discharged from the household to the household sewage treatment plant were presented by Wiejak (2013). The author demonstrated that the total phosphorus concentration in raw sewage, in the years 2011-2012, did not exceed the value of $6.5 \mathrm{mg} \cdot \mathrm{dm}^{-3}$. The average value of the analysed nutrient in the wastewater obtained by the author, amounting to $4.2 \mathrm{mg} \cdot \mathrm{dm}^{-3}$, is significantly lower than that found in this study, in the years 2003-2010. Decreased values of total phosphorus in wastewater were also reported in the publications by Chmielowski et al. (2020), Wałega et al. (2019), and Jucherski et al. (2019).

Unfortunately, the studies by other authors cited in the discussion are random, and short-term (maximum 4 years). These studies show a fragmentary decrease in phosphorus concentration, but such that was not described, analysed or statistically tested by the authors. In short periods, the aforementioned concentration of nitrogen may decrease, but then it often increases again. Based on the data from short-period observations, it cannot be concluded that the activities related to the reduction of phosphorus content in wastewater have brought effects.

In their article, Heidrich and Kozak (2009) point to the need of observing and testing pollutants' unit loads, because along with sewage flows they constitute the basic and most important parameters used in the design of sewage treatment plants. In order to meet these expectations, this paper analyses a 15 -year operation period of a sewage treatment plant. Research results are supported by advanced statistical analysis.

Summing up the obtained research results, the current activities in Poland and in Europe, intended to limit phosphorus content in washing products for dishwashers, washing machines and detergents commonly used to keep rooms clean, have to be positively assessed. However, it should be noted that even longterm research, carried out for many years but on a sin- gle object only, is insufficient to be able to state with certainty that the observed trend occurs throughout Poland. The author hopes that other researchers, who will have accumulated sufficiently long-term measuring sequences, shall undertake a similar analysis of phosphorus concentrations and loads in domestic sewage. Of course, it would be most beneficial to measure this nutrient in the wastewater discharged from each farm or public utilities. Such measurements would not be disturbed by possible phosphorus discharges from small-scale production facilities or its possible dilution with infiltration and / or accidental waters. Therefore, they would provide high degree of certainty for scientific inference.

\section{CONCLUSIONS}

Based on a 15-year study of the concentrations and loads of total phosphorus in domestic sewage discharged from single-family housing estates, the following conclusions were drawn:

- Multidirectional activities, introduced in recent years in Poland and Europe, and aimed at reducing the amount of phosphorus compounds in detergents, have significantly decreased the concentration and load of this nutrient in domestic sewage flowing into the analysed treatment plant.

- Over the past 15 years, the total phosphorus concentration in domestic sewage has decreased from 15.0 to $5.9 \mathrm{mg} \cdot \mathrm{dm}^{-3}$, i.e. by $60.1 \%$. Annually, in the years 2003-2017, the total phosphorus concentration decreased on average by $6.6 \%$.

- The observed trend of total phosphorus reduction in domestic sewage corresponds to a decrease in the unit load value, related per 1 inhabitant. In the analysed period of the research, the value of this measure decreased by $68 \%$ from $2.25 \mathrm{mg} \cdot$ person $^{-1} \cdot \mathrm{d}^{-1}$ in 2003 to $0.72 \mathrm{mg} \cdot$ person $^{-1} \cdot \mathrm{d}^{-1}$ in 2017.

- Reduction of phosphorus loads and concentrations in domestic sewage translates into better quality of treated sewage discharged to the receiving water body, in terms of the content of this nutrient. Total phosphorus concentration in the treated wastewater discharged from the tested sewage treatment plant with the capacity of $650 \mathrm{~m}^{3} \cdot \mathrm{d}^{-1}$ decreased in the years $2003-2017$ from 5.1 to $2.0 \mathrm{mg} \cdot \mathrm{dm}^{-3}$, i.e. by $60.8 \%$. 
- Limiting the phosphorus content in detergents contributed to a significant reduction of its load in treated wastewater discharged to flowing waters. For example, in $2003,2.16 \mathrm{~kg} \cdot \mathrm{d}^{-1}$ of total phosphorus was discharged into the water body, which is the right-bank tributary of the Vistula river, while in 2017 the corresponding figure was only $1.26 \mathrm{~kg} \cdot \mathrm{d}^{-1}$. Therefore, the daily load of the nutrient, which is a trophic threat to the water body, decreased by $0.90 \mathrm{~kg} \cdot \mathrm{d}^{-1}$, i.e. by $41.7 \%$.

- The observed regression of phosphorus content in the wastewater discharged into the sewage system translates into a lower risk of anthropopressure on flowing waters and the Baltic Sea, mainly in the aspect of initiating the eutrophication process. Based on the research, it was found that only for one analysed sewage treatment plant, the annual phosphorus content in the wastewater would reduce the trophic mass growth by nearly 33 tons, in comparison to the period when no restrictions were applied to the content of polyphosphate in detergents.

\section{REFERENCES}

Anderson, T.R., Hawkins, E., Jones, P.D. (2016). CO2, the greenhouse effect and global warming: from the pioneering work of Arrhenius and Callendar to today's Earth System Models. Open access, Research article Endeavour, 40, 3, 178-187.

Dymaczewski Z. (2011). Poradnik eksploatatora oczyszczalni ścieków. Poznań: PZITS.

Błażejewski, R. (ed.) (2003). Kanalizacja wsi. Poznań: PZITS Oddział Wielkopolski.

Bugajski, P., Kaczor, G. (2004). Temperatura jako czynnik wpływający na wielkość redukcji wybranych wskaźników zanieczyszczeń w przydomowej oczyszczalni TURBOJET EP-4. Inżynieria Rolnicza 2 (57), Komitet Techniki Rolniczej PAN, 187-198.

Chmielowski, K., Bedla, D., Dacewicz, E., Jurik, L. (2020). Effect of Parametric Uncertainty of Selected Classification Models and Simulations of Wastewater Quality Indicators on Predicting the Sludge Volume Index. Pol. J. Environ. Stud. 29, 2, 1-10.

Chmielowski, K., Mazur, R., Nowak, A., Bedla, D., Mazurkiewicz, J., Spychała, M. (2019). Efficiency of Nutrient Removal from Household Wastewater in Nonwoven Bioreactors. Pol. J. Environ. Stud. 28, 4, 2099-2108.

Ciml, J., Pečenka, J., Moravcová, J., Lechner, P., Kalíšek, J. (2015). Effect of land use on total phosphorus loss in selected locations. Acta Sci. Pol. Formatio Circumiectus 14(1), 3-14.

Cupak, A., Chmielowski, K., Bugajski, P., Dacewicz, E. 2019. Assessment of efficiency of rural sewage treatment plant with bioreactor. Acta Sci. Pol. Formatio Circumiectus, 18(1), 137-143.

Dąbrowska, L., Pawęska, K., Dąbek, P., Stodolak, R. (2017). The implications of economic development, climate change and european water policy on surface water quality threats. Acta Sci. Pol. Formatio Circumiectus 16 (3), 111-123.

Giagnorio, M., Amelio, A., Grüttner, H., Tiraferri, A. (2017). Environmental impacts of detergents and benefits of their recovery in the laundering industry. Journal of Cleaner Production, 154, 593-601.

Górecki, K. (2007). Zmiany stężenia i ładunku składników biogennych w wodzie rzeki warty między przekrojami Oborniki i Skwierzyna. Acta Sci. Pol., Formatio Circumiectus, 6 (3), 29-42.

Heidrich, Z., Kozak T. (2009). Jednostkowe ładunki zanieczyszczeń charakteryzujące ścieki miejskie, Gaz, Woda i Technika Sanitarna, nr 12, 20-23.

Henze, M., Harremoës, P., Jes la Cour, J., Arvin E. (2000). Oczyszczanie ścieków - procesy biologiczne i chemiczne (tłumaczenie M. Żygadło i B. Bartkiewicz). Wydaw. Politechniki Świętokrzyskiej: Kielce.

Jucherski, A., Walczowski A., Bugajski P., Jóźwiakowski K., (2019). Technological reliability of domestic wastewater purification in a small Sequencing Batch Biofilm Reactor (SBBR). Separation and Purification Technology, 224, 340-347.

Kaczor, G. (2012). Wpływ wód infiltracyjnych i przypadkowych na funkcjonowanie małych systemów kanalizacyjnych. Zeszyty Naukowe Uniwersytetu Rolniczego w Krakowie, rozprawy, 372, Wydawnictwo Uniwersytetu Rolniczego w Krakowie.

Kaczor, G., Bergel, T., Bugajski, P. (2015). Impact of extraneous waters on the proportion of sewage pollution indicesregarding its biological treatment. Infrastruktura i Ekologia Terenów Wiejskich, nr IV/3/2015, PAN Oddział w Krakowie, Kraków, 1251-1260.

Kaczor, G., Chmielowski, K., Bugajski, P. (2017). Influence of extraneous waters on the quality and loads of pollutants in wastewater discharged into the treatment plant. Journal Of Water And Land Development. 33, 1. 73-78.

Kaczor, G., Szewczyk, T. (2011). Wybrane cechy jakościowe ścieków odprowadzanych z osiedli domów jednorodzinnych w Krakowie. Gaz, Woda i Technika Sanitarna nr 10'2011, Warszawa: Wydawnictwo Sigma NOT, 361-363. 
Kogawa, A.C, Cernic, B.G., Domingos do Couto, L.G., Salgado, H.R.N. (2017). Synthetic detergents: 100 years of history. Saudi Pharmaceutical Journal, 25, 934-938.

Maciołek, P. Beata Janowska, B., Szymański K. (2016). Usuwanie azotu ze ścieków komunalnych z wykorzystaniem zewnętrznego źródła węgla organicznego. Annual Set The Environment Protection, 18, 885-896.

Majewski, W. (2015). Water Management in Poland. Acta Energetica, 1/22, 6-12.

Marzec, M. (2017). Reliability of removal of selected pollutants in different technological solutions of household wastewater treatment plants. Journal of Water and Land Development. 35, 141-148.

Marzec, M. (2018). Niezawodność technologiczna unieszkodliwiania zanieczyszczeń biogennych $\mathrm{w}$ wybranych technologiach stosowanych w małych oczyszczalniach ścieków. Przemysł Chemiczny, 97 (5), 753-757.

Moges, M.E., Todt, T., Eregno, F.E., Heistad, A. (2017). Performance study of biofilter system for on-site greywater treatment at cottages and small households. Ecological Engineering, 105, 118-124.

Policht-Latawiec, A., Bogdał, A., Kanownik, W., Kowalik, T., Ostrowski, K., Gryboś, P. (2014). Jakość i walory użytkowe wody małej rzeki fliszowej. Annual Set The Environment Protection, 16, 546-561.

Rozporządzenie Ministra Gospodarki, Pracy i Polityki Społecznej z dnia 26 czerwca 2003 r. w sprawie szczegółowych wymagań dla niektórych produktów ze względu na ich negatywne oddziaływanie na środowisko. (2003). Dz.U. 2003 nr 114 poz. 1078.

Rozporządzenie Ministra Gospodarki i Pracy z dnia 23 lipca 2004 r. w sprawie szczegółowych wymagań dla niektórych produktów ze względu na ich negatywne oddziaływanie na środowisko. (2004). Dz.U. 2004 nr 179 poz. 1846.

Rozporządzenie Ministra Gospodarki Morskiej i Żeglugi Śródlądowej z dnia 12 lipca 2019 r. w sprawie substancji szczególnie szkodliwych dla środowiska wodnego oraz warunków, jakie należy spełnić przy wprowadzaniu do wód lub do ziemi ścieków, a także przy odprowadzaniu wód opadowych lub roztopowych do wód lub do urządzeń wodnych. (2019). Dz.U. 2019 poz. 1311.

Rozporządzenie Parlamentu Europejskiego i Rady (UE) nr 259/2012 z dnia 14 marca 2012 r. zmieniające rozporządzenie (WE) nr 648/2004 w odniesieniu do stosowania fosforanów i innych związków fosforu w detergentach dla konsumentów przeznaczonych do prania i detergentach dla konsumentów przeznaczonych do au- tomatycznych zmywarek do naczyń. (2012). Dziennik Urzędowy Unii Europejskiej, L 94, 16-21.

Sojka, M., Jaskuła, J., Wicher-Dysarz, J. (2016). Ocena ładunków związków biogennych wymywanych ze zlewni rzeki Głównej w latach 1996-2009. Annual Set The Environment Protection. 18, 815-830.

Szpakowski, W., Szydłowski, M. (2018). Evaluating the Catastrophic Rainfall of 14 July 2016 in the Catchment Basin of the Urbanized Strzyza Stream in Gdańsk, Poland. Pol. J. Environ. Stud., 27 (2), 861-869.

Travis, W.R., Smith, J.B., Yohe, G.W. (2018). Moving toward $1.5^{\circ} \mathrm{C}$ of warming: implications for climate adaptation strategies. Current Opinion in Environmental Sustainability, 31, 146-152.

Wałęga, A., Chmielowski, K., Młyński, D. (2019). Nitrogen and Phosphorus Removal from Sewage in Biofilter - Activated Sludge Combined Systems. Pol. J. Environ. Stud., 28, 3, 1939-1947.

Wałega, A., Michalec, B. (2014). Characteristics of Extreme Heavy Precipitation Events Occurring in the Area of Cracow (Poland). Soil \& Water Res., 9,(4), 182-191.

Wałęga, A., Młyński, D., Bogdał, A., Kowalik, T. (2016). Analysis of the Course and Frequency of High Water Stages in Selected Catchments of the Upper Vistula Ba$\sin$ in the South of Poland. Water 8(9), 394, 1-15.

Wałega, A., Plesiński, K., Chmielowski, K., Satora, S. (2010). Możliwości zwiększenia efektywności usuwania ze ścieków azotu i fosforu w oczyszczalni w Łopusznej, Infrastruktura i Ekologia Terenów Wiejskich, nr 1/2010, PAN, Oddział w Krakowie, 111-123.

Wasag, Z. (2008). Wstępna ocena zmian jakości wody od ujęcia, poprzez oczyszczalnię, do odbiornika. Acta Sci. Pol., Formatio Circumiectus, 7(3), 43-50.

Wąsik, E., Chmielowski, K., Cupak, A., Kaczor, G. (2018). Stability Monitoring of the Nitrification Process: Multivariate Statistical Analysis. Pol. J. Environ. Stud., 27, $5,1-11$.

Wiejak, A. (2013). Redukcja fosforu ogólnego w ściekach z małych przydomowych oczyszczalni. Prace Instytutu Techniki Budowlanej, Quarterly 1(165), 21-27.

Zawilski, M., Brzezińska, A. (2003). Bilans ścieków i ładunków zanieczyszczeń dopływających do oczyszczalni ścieków z uwzględnieniem mokrej pogody. Ochrona Środowiska, 1, 25-30.

Ziernicka-Wojtaszek, A., Krużel, J. (2016). The Diversification of Air Temperature Trends in Poland (1981-2010). Pol. J. Environ. Stud., 25(5), 2205-2209. 


\section{ZMIANY STĘŻEŃ I ŁADUNKÓW FOSFORU OGÓLNEGO W ŚCIEKACH BYTOWYCH I OCZYSZCZONYCH W 15 LETNIM OKRESIE OBSERWACJI W ASPEKCIE OGRANICZENIA NEGATYWNEJ ANTROPOPRESJI NA JAKOŚĆ WÓD POWIERZCHNIOWYCH - STUDIUM PRZYPADKU}

\section{ABSTRAKT}

\section{Cel pracy}

Głównym celem badań było udowodnienie tezy, że wprowadzone w ostatnich latach formalnoprawne ograniczenia stosowania związków fosforu w detergentach wpłynęły istotnie na obniżenie stężenia i ładunku tego biogenu w ściekach surowych dopływających do wybranej oczyszczalni. Dodatkowo zbadano, czy obniżenie stężenia fosforu w ściekach surowych wpłynęło na zmniejszenie stężenia i ładunku fosforu w ściekach oczyszczonych, co ograniczyłoby negatywną antropopresję ścieków na jakość wód powierzchniowych.

\section{Materiały i metody}

W niniejszej pracy, w ciągu 15 letniego okresu badań (2003-2017), poddano obserwacji stężenia i ładunki fosforu ogólnego w ściekach bytowych dopływających do wybranej oczyszczalni, a także w ściekach oczyszczonych odprowadzanych do wód odbiornika. W ramach badań pobrano łącznie 148 próbek ścieków surowych oraz 114 próbek ścieków oczyszczonych. Wyniki badań poddano zaawansowanej analizie statystycznej przy wykorzystaniu m.in. testu Manna-Kendalla, Kołmogorowa Smirnowa, elementów statystyki opisowej, a także analizy regresji wraz z wybranymi testami istotności.

\section{Wyniki i wnioski}

Na podstawie badań wykazano, że wielokierunkowe działania, wprowadzone w celu ograniczenia ilości fosforanów w detergentach w Polsce oraz Europie, przyczyniły się istotnie do zmniejszenia stężenia oraz ładunku tego biogenu w ściekach bytowych dopływających do wybranej oczyszczalni. W ciagu ostatnich 15 lat stężenie fosforu ogólnego w ściekach uległo obniżeniu z 14,4 do $5,7 \mathrm{mg} \cdot \mathrm{dm}^{-3}$, czyli o $60,4 \%$. Tendencja ta miała przełożenie na obniżenie się wartości ładunku jednostkowego. Wartość tego parametru obniżyła się o $68 \%$ z wartości $2,25 \mathrm{mg} \cdot \mathrm{d}^{-1}$ na osobę w roku $2003 \mathrm{do} 0,72 \mathrm{mg} \cdot \mathrm{d}^{-1}$ na osobę w roku 2017 . Obniżenie się zawartości fosforu w ściekach surowych wpłynęło także na obniżenie stężenia tego biogenu w ściekach oczyszczonych z wartości $5,1 \mathrm{do} 2,0 \mathrm{mg} \cdot \mathrm{dm}^{-3}$, czyli o $60,8 \%$.

Słowa kluczowe: ścieki, fosfor ogólny, oczyszczalnia ścieków, kanalizacja, negatywna antropopresja 